\title{
First description of autumn migration of Sooty Falcon Falco concolor from the United Arab Emirates to Madagascar using satellite telemetry
}

\author{
SÁLIM JAVED, DAVID C. DOUGLAS, SHAHID KHAN, JUNID NAZEER SHAH \\ and ABDULLAH ALI AL HAMMADI
}

\section{Summary}

The movement and migration pattern of the 'Near Threatened' Sooty Falcon Falco concolor is poorly known. Sooty Falcons breed on the islands of the Arabian Gulf after arriving from their non-breeding areas that are mainly in Madagascar. In the first satellite tracking of the species we fitted a 9.5 g Argos solar powered transmitter on an adult breeding Sooty Falcon off the western coast of Abu Dhabi in the United Arab Emirates. The bird successfully undertook autumn migration to Madagascar, a known wintering area for the species. We document the Sooty Falcon's autumn migration route and stop-over sites. The adult Sooty Falcon initiated its migration at night and with tailwinds, and travelled mainly during daytime hours for 13 days over an inland route of more than $5,656 \mathrm{~km}$. The three stop-over sites in East Africa were characterised by moderate to sparse shrub cover associated with potential sources of water. We discuss the migration pattern of the tracked bird in relation to importance of non-breeding areas for Sooty Falcons and recent declines in numbers in their breeding range.

\section{Introduction}

The Sooty Falcon Falco concolor is a medium-sized falcon that breeds on the Arabian Peninsula including in the United Arab Emirates (UAE) (Aspinall 2010) and is distributed over a large range with an estimated global extent of occurrence of nearly $1,000,000$ to $10,000,000 \mathrm{~km}^{2}$. They breed in the deserts of North Africa from Eastern Libya and Egypt to Jordan and south-eastwards along the coasts of the Red Sea and Arabian Gulf to south-western Pakistan (Cramp and Simmons 1980) and undertake a long migration to their non-breeding areas, which are mostly in Madagascar and south-east Africa.

Sooty Falcons are present at their breeding areas on the Arabian Peninsula during the hottest months of the year from May to September. These are in mountainous desert areas with canyons, cliffs or small crags in hot and very arid zones without vegetation and also on some small coral islands. Nest attendance by the Sooty Falcon and the closely related Eleonora's Falcon Falco eleonorae coincides with autumn migration of passerines which the adult falcons often prey upon to feed their young (Walter 1979a).

Population size of the Sooty Falcon has only been roughly estimated. Past estimates have been 40,000 breeding pairs (del Hoyo et al. 1994) and 100,000 individuals (BirdLife International 2007). These indirect estimates were based on the proportion of non-breeding birds seen in Madagascar when compared with Eleonora's Falcon, where Sooty Falcon numbers were to times 
greater in an area of $1,000 \mathrm{~km}^{2}$ in western Madagascar (Moreau 1969, Walter 1979a, del Hoyo et al. 1994). However, a more recent review of the status of the species suggests that numbers are probably only a fraction of the previous estimates (Jennings and Sadler 2006), with the current population size estimated between 10,000 and 20,000 (BirdLife International 2009). The breeding population size remains very poorly known (del Hoyo et al. 1994) and Walter (1979b) suggested that the main breeding areas are still to be discovered. The current breeding estimate is based on the published records of approximately 500 pairs in the Arabian Gulf (Gaucher et al. 1995, Jennings and Sadler 2006).

The species is considered threatened in the Middle East where most pairs breed on small uninhabited islands (Shah et al. 2008). Due to revised estimates and recent decline in Sooty Falcon numbers, the species is now listed as 'Near Threatened' (BirdLife International 2008) and is a Category I species under the newly signed Memorandum of Understanding for the 'Conservation of Migratory Birds of Prey in Africa and Eurasia' (http://www.cms.int/species/raptors).

Field investigations on Sooty Falcon are limited to few studies. Booth (1961) reported on the breeding of the species in the Libyan Desert. The breeding ecology has been studied in the Negev Desert (Frumkin and Pinshow 1983), in Saudi Arabia (Gaucher et al. 1995), in Bahrain (Kavanagh and King 2008), in Oman (Walter 1979c, Frumkin and Clark 1988, McGrady et al. 2009) and in the UAE (Shah et al. 2008). In the Arabian region, Sooty Falcons are found in countries along the Red Sea coast, Arabian Gulf, and Gulf of Oman. Sooty Falcon numbers in the UAE have declined from an estimated 14 breeding pairs in 1994 (Aspinall 1994) to six pairs in 2008 (Shah et al. 2008). All the current Sooty Falcon nests are restricted to a group of small islands within a $200 \mathrm{~km}^{2}$ area in western Abu Dhabi, making the species one of the most threatened breeding birds in the UAE (Shah et al. 2008).

In this paper we describe the first use of satellite telemetry to track a Sooty Falcon from its breeding area in the Middle East to wintering areas in Madagascar. We discuss the autumn migration route, stop-over sites and areas used during the non-breeding season in relation to the species' conservation status at its breeding and non-breeding quarters.

\section{Methods}

\section{Capture site}

The capture site was Qasr Khuyain Island, UAE $\left(24.42442^{\circ} \mathrm{N}\right.$ to $51.52031^{\circ} \mathrm{E}$ ) (Javed et al. 2008). Qasr Khuyain forms part of an island group located near the UAE's western border with Saudi Arabia and consists of three small islands which are largely rocky and devoid of any vegetation.

\section{Capture and marking}

We placed a $6 \mathrm{~m}$ mist-net adjacent to a nest site on 3 September 2008. After a few hours, a single Sooty Falcon was caught in the net as it returned to incubate. As mainly females incubate (del Hoyo et al. 1994) we assumed that the bird captured and tracked was an adult female. We attached a 9.5 g solar Argos PTT 100 (Platform Transmitter Terminal; Microwave Telemetry Inc., Columbia, MD, USA) using the backpack harness method (Kenward 2001). We chose a backpack attachment because it had been successfully used on the similar sized Eleonora's Falcon (Gschweng et al. 2008, López-López et al. 2009, 2010). We constructed the harness with $0.33 \mathrm{~mm}$ Teflon ribbons (Bally Ribbon Mills, USA). Total mass of the harness was approximately $2 \mathrm{~g}$. The falcon was weighed and measured before deployment of the transmitter and also examined for any external injury. The combined weight of the transmitter and harness represented $4.4 \%$ of the body weight of the bird $(260 \mathrm{~g})$. The bird was released near the capture site soon after it was radio-tagged. 


\section{Location estimates}

The transmitter was programmed to transmit for $10 \mathrm{~h}$, followed by a $48 \mathrm{~h}$ period to accommodate solar charging (a 10 $\mathrm{h}$ on and $48 \mathrm{~h}$ off duty cycle). All hours of the day were sampled because periodicity of the duty cycle $(58 \mathrm{~h})$ was not a multiple of $24 \mathrm{~h}$. Locations were obtained using the CLS Argos System. Argos calculates PTT locations from the Doppler shifts in transmission frequency during the satellite overpass. Argos assigns a categorical accuracy level to each estimated location. The highest accuracy is Class 3 with a I SD error radius of $\leq 250 \mathrm{~m}$ and the lowest accuracy is Class o with I SD error of $>1,500 \mathrm{~m}$ (Argos User Manual, Section 3.4, http://www.argos-system.org/manual/). Location Classes 1 and 2 have 1 SD errors of 50o$1,500 \mathrm{~m}$ and $250-500 \mathrm{~m}$ respectively. Data are insufficient for Argos to estimate the accuracy of auxiliary location classes A, B, and Z.

All data were filtered by excluding improbable locations based on a filtering algorithm (D. Douglas http://alaska.usgs.gov/science/biology/spatial). Filtering criteria considered location class, distance moved, movement rate and turning angle. Locations were retained if their location class was 1,2 , or 3. Auxiliary locations (classes $\mathrm{O}, \mathrm{A}, \mathrm{B}$, and Z) within $5 \mathrm{~km}$ of a preceding or subsequent location were retained by virtue of spatial redundancy, and remaining auxiliary locations were retained only if resultant movement rates were $<33.3 \mathrm{~m} \mathrm{~s}^{-1}$ and the internal angles ( $\alpha$, in degrees) formed by preceding and subsequent vectors (of lengths $d_{1}$ and $\left.d_{2} \mathrm{~km}\right)$ were not suspiciously acute $(\alpha>-25+$ $B \times \ln \left[\right.$ minimum $\left.\left(d_{1}, d_{2}\right)\right]$, where $\left.B=15\right)$. We assigned $B=15$ because it performed well for our specific tracking data both before and during migration.

A migratory stop-over was identified when multiple locations within a single PTT duty cycle indicated little if any movement across the landscape. Kernel home ranges on the wintering grounds were calculated in Program-R using the "kernelUD" function in the package "adehabitat'. The kernel smoothing parameter was determined using the likelihood cross validation method described by Horne and Garton (2006). Wind conditions at key times during the migration were evaluated using the NOAA/ESRL web portal http://www.esrl.noaa.gov/psd to query the NCEP/NCAR 40-Year Reanalysis data set (Kalnay et al. 1996).

\section{Results}

\section{Location data}

The falcon was tracked for 133 days from the date of tagging until 13 January 2009. Although intermittent transmitter signals were obtained until November 2009, we presumed the bird died in January, due to lack of movement and stationary readings from an activity sensor. No location data were received from the PTT between 3 September and 16 September, 2008. A total of 304 locations were obtained from the tagged bird from the time of deployment. Of the 304 total locations obtained, nearly $35 \%$ belonged to higher accuracy location classes of 1,2 and 3 . In total, 218 locations were retained after filtering, of which $55 \%$ were members of location classes 1,2 , and 3 .

\section{Autumn migration}

After breeding, the radio-tagged bird migrated south to non-breeding areas in Madagascar, providing first ever documentation of the migration route of an adult Sooty Falcon. The autumn migration of this bird from the UAE took approximately 13 days and ranged over seven countries including the countries of origin and destination (Figure 1). During migration the falcon flew at least 5,656 km and used several stop-overs. The first location outside the UAE was obtained in Saudi Arabia on November 1, approximately $400 \mathrm{~km}$ south of the breeding site. The falcon was subsequently located at stop-over sites in Ethiopia on 3 November, in north-eastern Kenya on 6 November, and southern Kenya on 8 November. On 11 November, the falcon was relocated in flight as it crossed from south-eastern Tanzania into Mozambique. The last locations from 


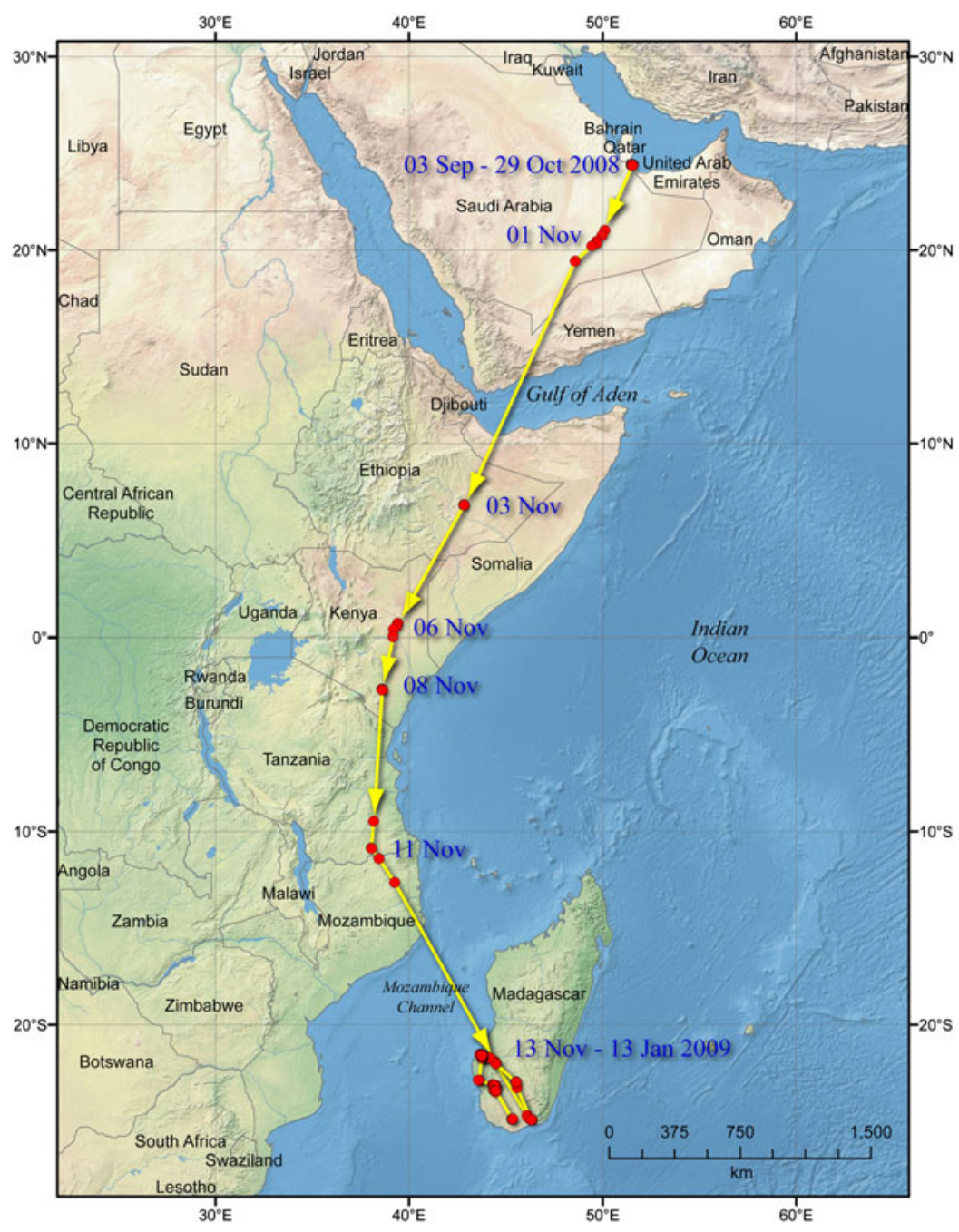

Figure 1. Autumn migration route of a single adult Sooty Falcon (Falco concolor) tracked from its breeding area in western Abu Dhabi in the UAE to its wintering areas in southern Madagascar. Tracking chronology annotated with blue text. Base map courtesy of Tom Patterson www. shadedrelief.com

Mozambique were approaching the south-east coast of the country. The falcon crossed the Mozambique Channel and arrived in Madagascar no later than 13 November when the first location was recorded near the Mangoky River about $140 \mathrm{~km}$ inland from the coast.

\section{Stop-over locations}

Three stop-over sites were identified in the tracking data by virtue of consecutive withinduty-cycle locations that indicated little or no movement: Ethiopia on 3 November and Kenya on November 6 and November 8 (Figure 1). The Global Land Cover 2000 map of the world (http:// bioval.jrc.ec.europa.eu/) classified the vegetation cover at these stop-overs as sparse, open, and closed grasslands, respectively. However, regional vegetation maps and satellite imagery indicate 
that all three stop-over sites were interspersed with sparse to moderate shrub cover. Location of the Ethiopia stop-over on 3 November $\left(6.831^{\circ} \mathrm{N} .42 .842^{\circ}\right.$ E, elevation $\left.\sim 535 \mathrm{~m}\right)$, when overlaid on satellite imagery from Google Maps ${ }^{\odot}$, shows the falcon occupied an arid region of sparse shrub cover flanking the banks of what are likely to be seasonally ephemeral streams (http://maps.google. $\mathrm{com} / \mathrm{maps} ? \mathrm{ll}=6.831,42.842 \& \mathrm{z}=18 \& \mathrm{t}=\mathrm{e}$ ). In Kenya, a Landsat-derived land cover map (Africover, www.africover.org) classified vegetation at both stop-over sites as open shrub with $40-45 \%$ crown cover. The first stop-over site in Kenya (6 November, $0.712^{\circ} \mathrm{N}, 39.411^{\circ} \mathrm{E}$, elevation $\sim 200 \mathrm{~m}$ ) was on a well-established delta floodplain formed by tributaries of the Ewaso $\mathrm{Ng}$ 'iro River near its headwaters (http://maps.google.com/maps?ll $=0.712,39.411 \& \mathrm{z}=11 \& \mathrm{t}=\mathrm{e}$ ). The second stop-over site in Kenya ( 8 November, $2.697^{\circ} \mathrm{S}, 38.619^{\circ} \mathrm{E}$, elevation $\sim 460 \mathrm{~m}$ ) was in west-central Tsavo National Park East in an extensive and remote region of scrubland savannah $25 \mathrm{~km}$ east of the Athi River (http://maps.google.com/maps?ll=-2.697,38.619\&z=11\&t=e).

\section{Migration timing}

In-flight locations from the tracked Sooty Falcon were primarily obtained during morning hours, and locations during stop-overs were primarily obtained during evening hours (Figure 2). This suggests the Sooty Falcon's migration may have been strictly diurnal, stopping at night and moving by day. There was, however, indirect evidence of one exception at the beginning of the migration. The first post-departure locations in Saudi Arabia (Figure I) showed the falcon was inflight and travelling at a speed of $44 \mathrm{~km} \mathrm{~h}^{-1}$. Back projecting $44 \mathrm{~km} \mathrm{~h}^{-1}$ over the elapsed $400 \mathrm{~km}$ distance from the nest site would place the departure time on the evening of 31 October 2008 at 19h3o local time (Table I). If correct, then the Sooty Falcon departed its breeding area in the UAE and commenced autumn migration at night, and at a time that coincided with prevailing $8 \mathrm{~m} \mathrm{~s}^{-1}$ $\left(29 \mathrm{~km} \mathrm{~h}^{-1}\right)$ tail winds (Figure $\left.3 \mathrm{a}\right)$, while its migration across eastern Africa coincided with generally modest $<2.7 \mathrm{~m} \mathrm{~s}^{-1}\left(<10 \mathrm{~km} \mathrm{~h}^{-1}\right.$ ) onshore easterlies (Figures $3 \mathrm{~b}$ and $3 \mathrm{c}$ ). We inspected wind speed, direction, and relative vorticity throughout the migration and did not find any obvious weather events that corresponded with the stop-over locations and chronologies. However, the prevailing onshore easterly winds clearly intensified during the late afternoon which may have influenced the falcon's tendency to migrate earlier in the day.

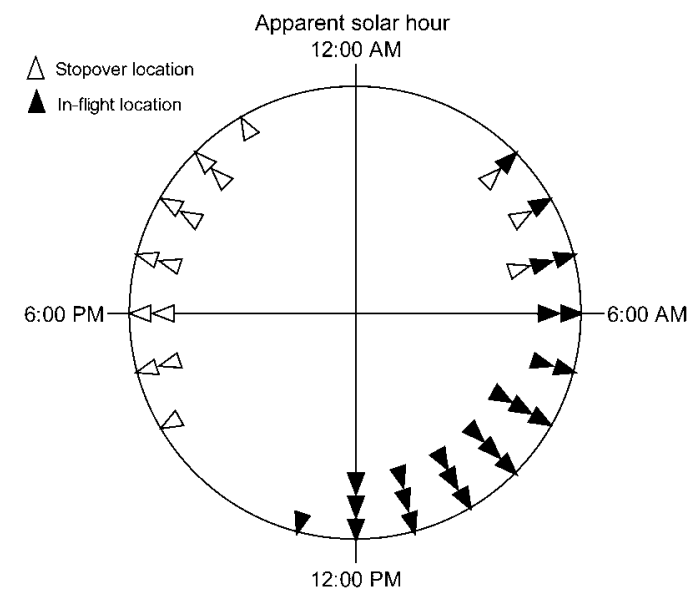

Figure 2. Diurnal frequency distribution of Sooty Falcon locations obtained by satellite telemetry during autumn migration from the UAE to Madagascar, partitioned into two migratory behaviour categories: 1) stop-over; and 2) in flight. 
Table 1. Autumn migration chronology of an adult Sooty Falcon tracked by satellite between its nesting area in the UAE and its wintering area in south-west Madagascar. Between departure and destination, the transmitter provided five intervals (duty cycles) of tracking data.

\begin{tabular}{|c|c|c|c|c|c|c|c|}
\hline Geographic locale & $\begin{array}{l}\text { Local } \\
\text { date-time }\end{array}$ & $\begin{array}{l}\text { Initial } \\
\text { latitude }\end{array}$ & $\begin{array}{l}\text { Initial } \\
\text { longitude }\end{array}$ & $\begin{array}{l}\text { Elapsed } \\
\text { distance } \\
(\mathrm{km})\end{array}$ & $\begin{array}{l}\text { Elapsed } \\
\text { time } \\
\text { (hr) }\end{array}$ & $\begin{array}{l}\text { Elapsed } \\
\text { rate } \\
(\mathrm{km} / \mathrm{hr})\end{array}$ & $\begin{array}{l}\text { Duty cycle } \\
\text { flight status }\end{array}$ \\
\hline $\begin{array}{l}\text { Abu Dhabi } \\
\quad(\text { departure })^{\mathrm{a}}\end{array}$ & $\begin{array}{c}31 / 10 / 2008 \\
19 h_{30}\end{array}$ & $24 \cdot 38$ & 51.53 & & & & \\
\hline South Saudi Arabia & $\begin{array}{c}\text { O1/II/2008 } \\
\text { O3h35 }\end{array}$ & 21.02 & 50.10 & 400 & 9.1 & 44.0 & In flight \\
\hline Eastern Ethiopia & $\begin{array}{c}03 / 11 / 2008 \\
17 h_{42}\end{array}$ & 6.83 & 42.86 & 1,768 & 62.1 & 28.5 & Stop-over \\
\hline Eastern Kenya & $\begin{array}{c}\text { o6/11/2008 } \\
\text { o4ho4 }\end{array}$ & 0.71 & 39.43 & 785 & 58.4 & 13.4 & $\begin{array}{c}\text { Stop-over and } \\
\text { departure }\end{array}$ \\
\hline Southeast Kenya & $\begin{array}{c}\text { 08/11/2008 } \\
\text { 16h40 }\end{array}$ & -2.67 & 38.59 & 393 & 60.6 & 6.5 & Stop-over \\
\hline $\begin{array}{l}\text { Tanzania to } \\
\text { Mozambique }\end{array}$ & $\begin{array}{c}11 / I_{1} / 2008 \\
\text { o5h28 }\end{array}$ & -9.48 & 38.17 & 767 & 60.8 & 12.6 & In flight ${ }^{b}$ \\
\hline $\begin{array}{l}\text { Madagascar } \\
\quad \text { (destination) }\end{array}$ & $\begin{array}{c}13 / 11 / 2008 \\
17 h_{16}\end{array}$ & -21.85 & $44 \cdot 37$ & 1,545 & 59.8 & 25.8 & \\
\hline TOTAL $^{c}$ & & & & 5,656 & 311.7 & & \\
\hline
\end{tabular}

${ }^{a}$ Departure time estimated based on a $44 \mathrm{~km} \mathrm{hr}^{-1}$ back-trajectory from the first location in Saudi Arabia

${ }^{\mathrm{b}}$ Average tracking rate during this in-flight duty cycle $=46.7 \mathrm{~km} \mathrm{hr}^{-1}$

${ }^{\mathrm{c}}$ Average tracking rate $=18.1 \mathrm{~km} / \mathrm{hr}, 437 \mathrm{~km}$ day $^{-1}$

Pace of the falcon's migration across the landscapes of eastern Africa was variable (Table 1 ). The elapsed time between duty cycles was relatively constant (58.4-62.1 h), but the distances moved between duty cycles spanned a wide range $(393-1,768 \mathrm{~km})$. Migration rate was highest at the beginning and end of the 13 -day journey. If we assume the falcon migrated diurnally for roughly $10-12 \mathrm{~h} \mathrm{~d}^{-1}$ at $40-45 \mathrm{~km} \mathrm{~h}^{-1}$, then at least two other unidentified stop-over sites were probably used (but unobserved due to the PTT's duty cycle): one between Saudi Arabia and Ethiopia, and one between Mozambique and Madagascar. Similarly within Kenya, the falcon must have either stopped for multiple days at the site in Tsavo National Park East, or it must have stopped earlier at an unidentified site.

The Sooty Falcon was located flying across the Tanzania and Mozambique border on 11 November during a single $10 \mathrm{~h}$ duty cycle with an average tracking velocity of $46.7 \mathrm{~km} \mathrm{~h}^{-1}$. The Sooty Falcon's migration across the Mozambique Channel, from the north-east coast of Mozambique to south-west Madagascar, traversed a region where prevailing easterly headwinds in the southern Indian Ocean are bifurcated by the terrain of Madagascar (Figure 3c). Assuming the falcon stopped for the night in Mozambique and commenced migration to Madagascar on the morning of 12 November, then evidence of a slight tailwind accompanies the presumed time of departure (Figure $3 \mathrm{~d}$ ).

\section{Austral summer movement}

A kernel home range analysis of location data obtained after the falcon arrived in Madagascar documents exclusive use of the southern part of the country (Figure 4). After arriving in Madagascar, the falcon briefly occupied a site in south-western Madagascar before flying another $540+\mathrm{km}$ to the far southern end of the island on November 16 , and then promptly returned north to the region where it first arrived (Figure 4). The falcon then occupied the Mangoky River floodplain for about one month (21 November to 21 December) among cultivated bottom lands and adjacent wooded grasslands and brush. The falcon then moved south, and then inland where it spent $\sim 2$ weeks (26 December to 7 January) $30 \mathrm{~km}$ south-west of the town of Sakaraha in an area of wooded grasslands in close proximity to cultivated areas. The falcon's final movement was to 
a) October $31,2008,18: 00 \mathrm{GMT}$

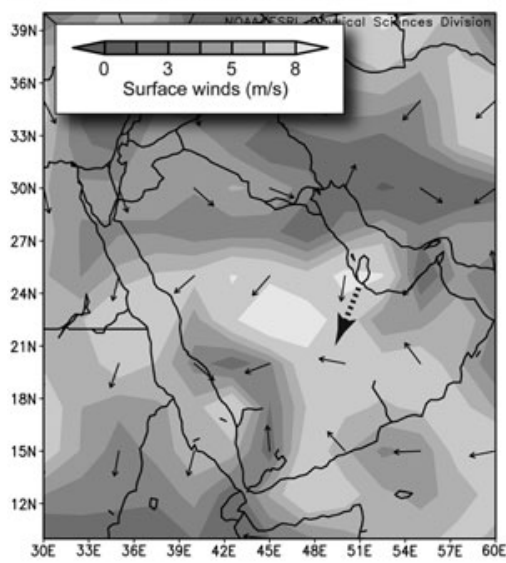

C) November climatology, 1968 - 1996

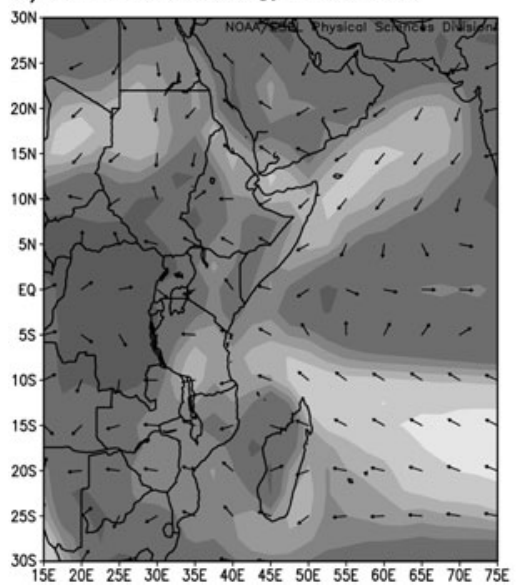

b) November 06, 2008, 06:00 GMT

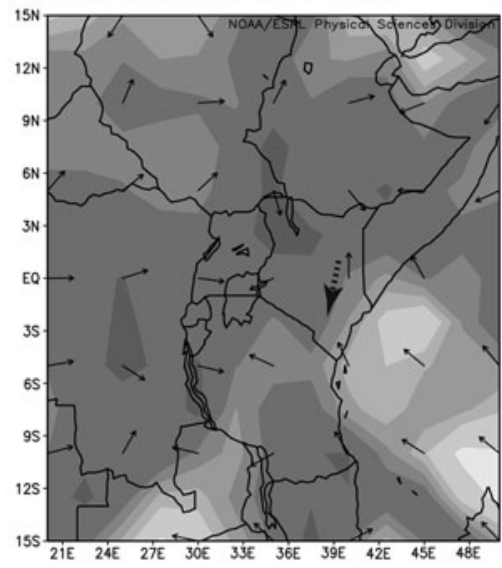

d) November 12, 2008, 06:00 GMT

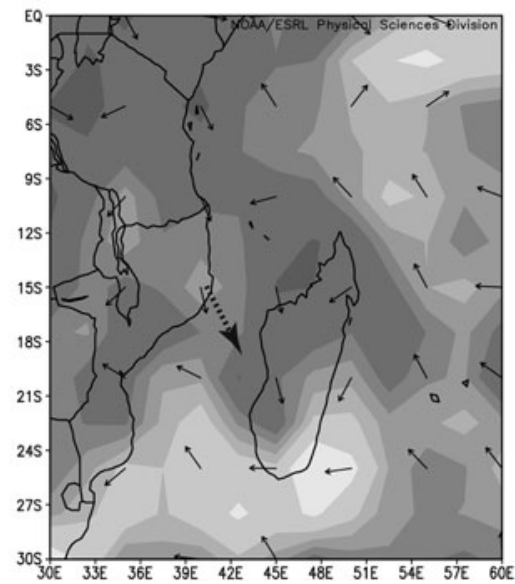

Figure 3. Surface wind conditions (a) at the estimated departure time of a Sooty Falcon commencing autumn migration from UAE to Madagascar; (b) at the time the falcon departed a stop-over in Ethiopia; (c) long-term November climatology; and (d) at the estimated time the falcon migrated across the Mozambique Channel. Bold hatched arrows denote the general migration trajectory of the Sooty Falcon. Graphic provided by the NOAA/ESRL Physical Sciences Division, Boulder Colorado from their Web site at http://www.esrl.noaa.gov/psd/

return to southernmost Madagascar. The transmitter came to rest about $30 \mathrm{~km}$ inland on 15 January 2009, and for several months thereafter provided highly intermittent and stationary data with no indication of activity from an onboard motion sensor, leading us to conclude that the falcon had likely died.

\section{Discussion}

\section{Autumn migration}

Capture and tagging of an adult Sooty Falcon and successful tracking of its autumn migration from its breeding area in the Arabian Gulf to its non-breeding grounds in Madagascar is the first 

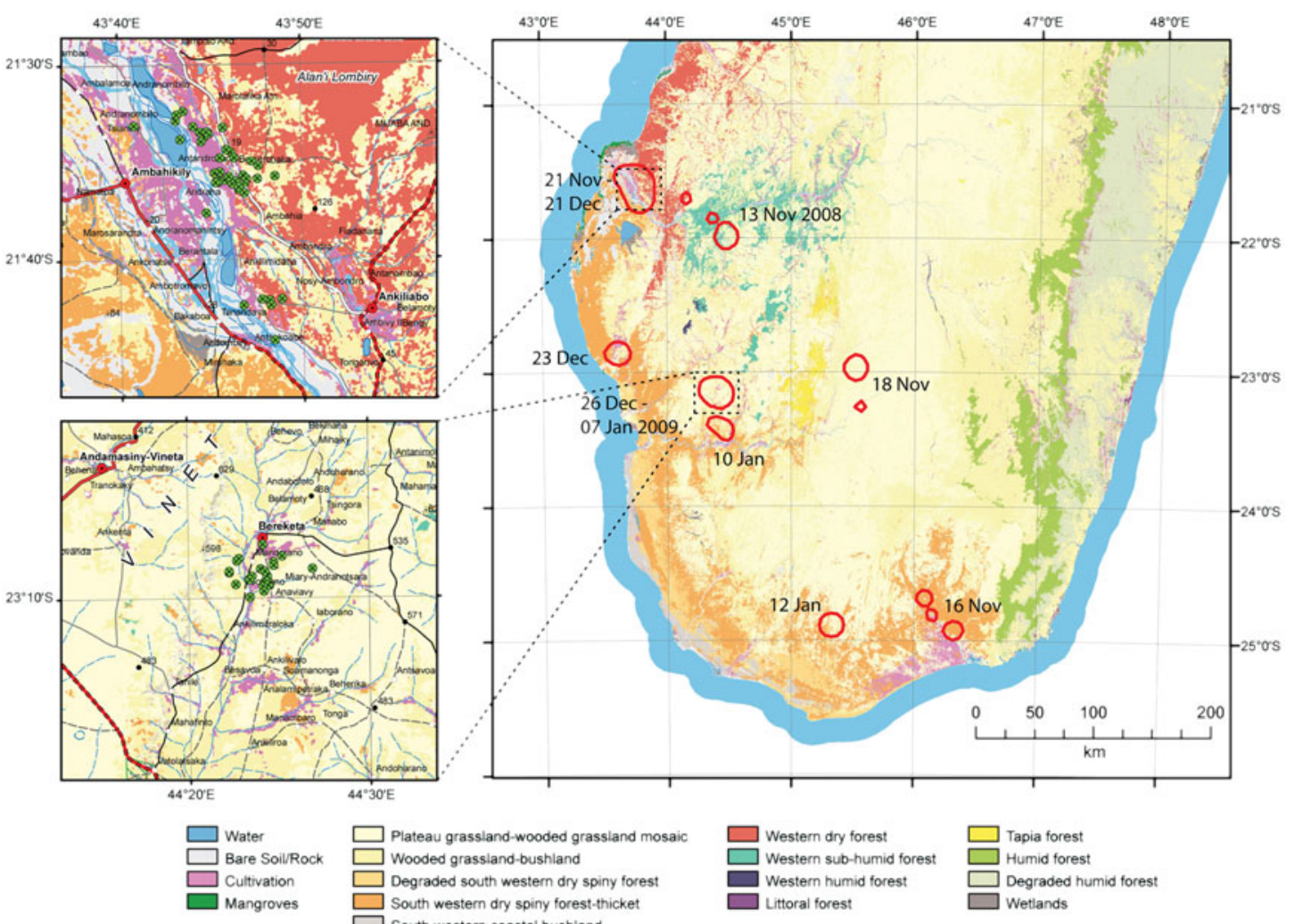

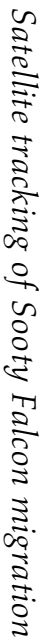

Figure 4. Winter use areas (red polygons) of an adult Sooty Falcon in relation to land cover in south-western Madagascar. Falcon use areas are delineated by a fixed-kernel $95 \%$ utilisation distribution that was derived with a likelihood cross-validation smoothing parameter. Insets detail two areas of extended occupancy in which individual standard-class (I-sigma error $<1.5 \mathrm{~km})$ satellite relocations are overlaid (green circles). Land cover map from the Critical Ecosystem Partnership Fund Madagascar Vegetation Mapping Project http://www.kew.org/gis/projects/mad_veg/ 
such documentation for the species. The study also provided important information on stop-overs used during migration and areas used after arriving in Madagascar.

The Sooty Falcon migrated from UAE to Madagascar over land with the exception of two required ocean crossings: the Gulf of Aden and the Mozambique Channel. The three documented stop-overs in East Africa were in natural grasslands with sparse to moderate shrub cover. The presence of water sources in the immediate or near vicinity of the three stop-overs suggests the falcon may have stopped to refuel. In 2008, like most years, a period of extreme dryness in East Africa from June to September was followed by a short rainy season from mid-October to mid-December (http://www.esrl.noaa.gov/psd). Stopping at sites which tend to accumulate water in a very arid environment possibly provides a better opportunity to hunt small birds and arthropods. Migratory raptors time their migration to take advantage of prevailing weather conditions and an increased opportunity to feed at stop-over sites. Such weather-dependent stopover sites could be of critical importance to Sooty Falcons and many other migratory raptors (Bildstein et al. 2000, Symes and Woodborne 2010).

The Sooty Falcon locations we obtained during migration showed a distinct diurnal pattern: the bird was tracked in flight primarily during day time hours and at rest during evening hours. The transmitter's duty cycle precluded uninterrupted tracking, so it is not possible to ascertain if the bird maintained a strict schedule of daytime movements. By contrast, the tracking data suggest the falcon initially departed UAE in the evening, crossing the first $400 \mathrm{~km}$ of Arabian Desert at night.

During its 13-day, 5,656-km journey to Madagascar, the Sooty Falcon did not consistently migrate at an average rate $\left(435 \mathrm{~km} \mathrm{~d}^{-1}\right)$. There was considerable variability in the falcon's dayto-day progress across the landscape. The migration notably slowed in Kenya, where the bird probably spent at least three nights within a range of $393 \mathrm{~km}$. The extra time spent in Kenya was compensated by progressing faster than average at both the beginning and end of the migration. These observations indicate that the Sooty Falcon deviated from a persistent migration schedule, possibly in response to environmental (weather) conditions or energy requirements. Variability in daily travel schedule of the Eurasian Hobby Falco subbuteo has been attributed to a flyand- forage strategy adopted by the birds as they move across different regions (Strandberg et al. 2009a).

Migratory raptors are known to make changes in flight courses or to make very slow progress while crossing the Sahara, and in extreme cases may interrupt crossing during daytime in response to weather events such as dust storms and severe headwinds (Strandberg et al. 2009b, López-López et al. 2010). In addition to ecological barriers, the migratory behaviour of birds can also be shaped by meteorological barriers (Mellone et al. 2010). When the falcon in this study migrated across East Africa, wind conditions comprised modest onshore easterlies $\left(<10 \mathrm{~km} \mathrm{~h}^{-1}\right)$, suggesting that winds were probably not a principal factor dictating the timing and location of stop-overs for this specific migration.

The onset of migration from the breeding area on the evening of October 31 coincided with prevailing tailwinds of approximately $29 \mathrm{~km} \mathrm{~h}^{-1}$. The likely absence of a stop-over in the desert of Saudi Arabia and the likely evening departure of the falcon from its breeding ground may represent a migration strategy to quickly and efficiently pass through an area which offers limited opportunities to forage (López-López et al. 2010). Migration rate across the landscape was highest between UAE and the first documented stop-over in Ethiopia $\left(\sim 730 \mathrm{~km} \mathrm{~d}^{-1}\right)$. Although our results are constrained by sample size, López-López et al. (2010) reported a similar migratory strategy in which Eleonora's Falcons increased their nocturnal travel rate and did not stop during daytime while moving across the Sahara.

The Sooty Falcon migrated inland through East Africa, east of the eastern Rift Valley until reaching northern Mozambique. Routes along the East African countries are also used by the Eurasian Hobby (Strandberg et al. 2006) and Eleonora's Falcon (Gschweng et al. 2008, LópezLópez et al. 2009, 2010), suggesting that the similarity in migratory behaviour is possibly due to close phylogenetic relationships between Sooty Falcon and other members of the Falco clade, 
which includes Eleonora's Falcon, Eurasian Hobby, Red-footed Falcon F. vespertinus, Amur Falcon F. amurensis and African Hobby F. cuvieri. All of these species have shared ancestry (Wink and Ristow 2000) and also share similar non-breeding areas in south-eastern Africa (Ferguson-Lees and Christie 2001).

The closely related Eleonora's Falcon, tracked from their breeding colonies on the Balearic Islands (López-López et al. 2009, 2010) and in Sardinia (Gschweng et al. 2008) to non-breeding grounds in Madagascar, also followed an inland route over Africa - contrary to a presumed route across the Mediterranean (Stresemann 1954, Walter 1979a). It is not known for certain, however, if Sooty Falcons use the same inland route during spring migration or use coastal routes to return to their breeding grounds, but Lewis and Pomeroy (1989) suggest the autumn and spring migration routes may differ. Eleonora's Falcons demonstrate high inter- and intra-individual variability in use of autumn and spring migration routes and stop-over sites (Gschweng et al. 2008). Eleonora's Falcons change migration route from one year to another in response to weather condition (Mellone et al. 2010).

From the tracking of Sooty Falcon and Eleonora's Falcon (Gschweng et al. 2008, López-López et al. 2010), it is likely that Mozambique is the convergence point for all birds of these two species that breed in the Mediterranean, the Middle East and North Africa. Eastern Mozambique likely serves as a migratory conduit for all Sooty and Eleonora's Falcons before they undertake an openocean flight across the Mozambique Channel. Whether Sooty Falcons use the same route during spring migration is not known. However, Eleonora's Falcon takes a more direct route from Madagascar to Tanzania and Somalia in the spring, by skirting north of the Mozambique Channel and following prevailing tailwinds across $1,500 \mathrm{~km}$ of open ocean (Mellone et al. 2010).

The Sooty Falcon we tracked crossed the Mozambique Channel during November 11-13, which is consistent with the mid-November crossing time reported for Eleonora's Falcon (Gschweng et al. 2008), however a relatively late mid-December crossing of Eleonora's Falcons has also been reported (López-López et al. 2009, 2010). Flying across the ocean between Mozambique and western Madagascar in November is not only strategic due to the minimised distance (Gschweng et al. 2008), but also the probability of wind resistance is reduced because Madagascar's terrain tends to block and bifurcate the prevailing easterlies in the southern Indian Ocean (Figure 4a). Had the tracked Sooty Falcon stopped in Mozambique for the night of 11 November, and departed for Madagascar on the morning of 12 November (i.e. adhering to its diurnal behaviour), the falcon's flight would have been assisted by modest tailwind conditions (Figure $4 \mathrm{~b}$ ).

A minimal distance across open water and reduced wind resistance highlights the importance of a migratory conduit through eastern Mozambique for the Sooty Falcon and Eleonora's Falcon, and a need for conservation of the area to provide safe staging and passage to the non-breeding areas in Madagascar, particularly during autumn migration.

\section{Local movement and habitat use}

The tracked Sooty Falcon first arrived in south-western Madagascar, and then flew to the far southern end of the country before promptly returning to the Mangoky River Delta region near its initial arrival point. This brief round trip quickly traversed about $800 \mathrm{~km}$. It is possible that an initial assessment of prey opportunities was unsatisfactory at the southernmost destination, which prompted the bird to immediately return to the Mangoky River floodplain where it spent nearly a month in a low-elevation $(\sim 30 \mathrm{~m})$ area of wooded grassland and brush mosaics adjacent to cultivated bottom lands (Figure 5). In late December, the Sooty Falcon moved and spent two weeks in a higher elevation $(\sim 330 \mathrm{~m})$ valley that was also in proximity to cultivated lands. Although the tracked falcon demonstrated a somewhat nomadic behaviour in its non-breeding distribution, possibly in response to ephemeral changes in prey abundance, south-western Madagascar in general is recognised as a favoured wintering area for Sooty Falcons (Zefania 2001).

The tracked Sooty Falcon consistently used areas close to cultivated farmlands in the southwestern part of Madagascar, possibly due to higher abundance of arthropods which are a primary 
source of food for the species at their wintering grounds. Amur Falcons in their wintering quarters predominantly prey upon abundant arthropods (Kopij 2009) and the non-breeding season of the Sooty Falcon in Madagascar is characterised by hot and wet weather with high arthropod abundance (Zefania 2001). Agriculture in Madagascar remains underdeveloped, but broad-scale use of harmful pesticides to control locust plagues in the past have had detrimental effects on arthropods and insectivorous vertebrates in the Malaimbandy area of southern Madagascar (Peveling et al. 2003). Nearly $70 \%$ of the residents of Malaimbandy practice farming and regular use of harmful pesticides is likely to have long-term consequences to wildlife due to food deprivation, increased intraspecific competition and possible effects on reproductive success (Peveling et al. 2003). Malaimbandy and other areas such Morondava in southern Madagascar are important wintering areas for a large number of Sooty Falcons (Zefania 2001) and possibly a high proportion of the entire total world population of the species, so the use of harmful pesticides could have severe long-term population consequences for the species. However, the extent of use of harmful chemicals and other land use practices on the Sooty Falcon is not known and should be a topic for future research.

\section{Conclusions}

Successful satellite tracking of a single adult Sooty Falcon from the UAE to Madagascar provides empirical evidence that these small falcons can be tracked with a $9.5 \mathrm{~g}$ transmitter, although the weight approached $4.4 \%$ of the bird's total body weight. Our data are insufficient to ascertain the cumulative effects of wearing a transmitter of this size, but with the newly available $5 \mathrm{~g}$ satellite transmitter (Microwave Telemetry), it will be possible to track Sooty and other small falcons with even less concern about transmitter weight issues.

The Sooty Falcon tracked in this study bred in the UAE and migrated 5,656 km to Madagascar during a 13-day journey in early November. The falcon appears to have commenced its migration at night to initially cross the Arabian Desert. The falcon followed an inland route through eastern Africa, primarily moving during the day and resting at night. Pace of migration across the landscape was variable and included multiple stop-overs with at least three nights spent in Kenya. Confirmed stop-over sites $(n=3)$ were located in relatively remote scrubland habitats, two of which were associated with riparian landforms. The Sooty Falcon migrated to the eastern coast of Mozambique where headwinds and distance to Madagascar were minimised. While in Madagascar, the Sooty Falcon occupied areas within or near to cultivated lands, potentially to capitalise on greater abundance or diversity of prey.

Recognising that our results are based on a single Sooty Falcon, we propose that future satellite tracking studies of adult and juvenile Sooty Falcons during spring and autumn would yield a more complete understanding of the migration ecology and non-breeding habitat requirements for a key species targeted under the Memorandum of Understanding for the Conservation of Migratory Birds of Prey in Africa and Eurasia. In fact, a new study started in 2010 is tracking two nestling Sooty Falcons from their natal sites in Oman (http://sootyfalconoman.blogspot.com/).

\section{Acknowledgements}

This study was funded by the Government of Abu Dhabi, United Arab Emirates through the Environment Agency - Abu Dhabi. We thank the management of the Environment Agency-Abu Dhabi for their support. The study is one of the components of the Bird Assessment and Monitoring Project (Project \# 03-31-0023-10). We also acknowledge the support of naval staff at Ras Ghumais for their support and permission to capture the bird. We thank Marion Gschweng and Mark Fuller for their useful comments on earlier drafts of this manuscript. The manuscript greatly benefitted from the comments made by Pascual López-López and an anonymous reviewer. 


\section{References}

Aspinall, S. J. (1994) Sooty Falcons in the United Arab Emirates. Tribulus 4: 18-20.

Aspinall, S. J. (2010) Breeding Birds of the United Arab Emirates. Abu Dhabi, UAE: Environment Agency-Abu Dhabi.

Bildstein, K. L., Zalles, J. I., Otinger, J. and McCarty, K. (2000) Conservation biology of the world's migratory raptors: status and strategies. Pp. 573-590 in R. D. Chancellor and B-U. Meyburg, eds. Raptors at risk. Surrey, BC., Canada: Hancock House and World Working Group on Birds of Prey.

BirdLife International (2007) Falco concolor. In IUCN 2007. IUCN Red List of Threatened Species. www.iucnredlist.org. Downloaded on $12 / 11 / 2007$

BirdLife International (2008) Falco concolor. In: IUCN 2010. IUCN Red List of Threatened Species. Version 2010.1. www.iucn redlist.org. Downloaded on 4/5/2010.

BirdLife International (2009) Species factsheet: Falco concolor. Downloaded from http://www.birdlife.org. Downloaded on 4/5/2010

Booth, B. D. (1961) Breeding of the Sooty Falcon in the Libyan Desert. Ibis 103: 129-130.

Cramp, S. and Simmons, K. E. L. (1980) The birds of the Western Palaearctic. Vol. 2 Hawks to bustards. Oxford, UK: Oxford University Press.

del Hoyo, J., Elliott, A. and Sargatal, J., eds. (1994) The handbook of birds of the world. Vol. 2 New World vultures to guineafowl. Barcelona: Lynx Edicions.

Ferguson-Lees, J. and Christie, D. A. (2001) Raptors: birds of prey of the world. London, UK: A\&C Black Publishers.

Frumkin, R. and Clark, S. (1988) Is there a dark morph of the Sooty Falcon Falco concolor? Ibis 130: 569-571.

Frumkin, R. and Pinshow, B. (1983) Notes on the breeding ecology and distribution of the Sooty Falcon Falco concolor in Israel. Ibis 125: 251-259.

Gaucher, P., Thiollay, J. and Eichaker, X. (1995) The Sooty Falcon Falco concolor on the Red Sea coast of Saudi Arabia: distribution, numbers and conservation. Ibis 137 : 29-34.
Gschweng, M., Kalko, E. K. V., Querner, U., Fiedler, W. and Berthold, P. (2008) All across Africa: highly individual migration routes of Eleonora's Falcon. Proc. R. Soc. B 275: 2887-2896.

Horne, J. S. and Garton, E. O. (2006) Likelihood cross-validation vs. least squares crossvalidation for choosing the smoothing parameter in Kernel Home Range Analysis. J. Wildl. Manage. 70: 641-648.

Javed, S., Khan, S. B., Nazeer, J. and Hammadi, A. (2008) First ever satellite tracking of Sooty Falcon from the United Arab Emirates. Abu Dhabi, UAE: Environment Agency - Abu Dhabi. Unpublished Report.

Jennings, M. C. and Sadler, T. A. (2006) A report on the activity of the small birds of prey and owls group: Conservation workshop of the fauna of Arabia, Desert Park Sharjah, 19-23, February, 2006. Sharjah, UAE: Environment and Protected Areas Authority.

Kavanagh, B. and King, H. (2008) Observations from 1998-2006 on the breeding population of Sooty Falcons Falco concolor on the Hawr Islands, Kindgdom of Bahrain. Sandgrouse 30: 70-76.

Kalnay, E., Kanamitsu, M., Kistler, R., Collins, W., Deaven, D., Gandin, L., Iredell, M., Saha, S., White, G., Woolen, J., Zhu, Y., Chelliah, M., Ebisuzaki, W., Higgins, W., Janowiak, J., Mo, K. C., Ropelewski, C., Wang, J., Leetmaa, A., Reynolds, R., Jenne, R. and Jospeh, D. (1996) The NCEP/NCAR 4-Year Reanalysis Project. Bull. Am. Meteorol. Soc. 77: 437-471.

Kenward, R. ed. (2001) A manual for wildlife radio tagging. London, UK: Academic Press.

Kopij, G. (2009) Seasonal variation in the diet of the Amur Kestrel (Falco amurensis) in its winter quarters in Lesotho. J. Afr. Ecol. 48: 559-562.

Lewis, A. D. and Pomeroy, D. E. (1989) A bird atlas of Kenya. Rotterdam, Netherlands: Balkema Publishers.

López-López, P., Liminana, R. and Urios, V. (2009) Autumn migration of Eleonora's 
falcon Falco eleonorae tracked by satellite telemetry. Zool. Stud. 48: 485-491.

López-López, P., Liminana, R., Mellone, U. and Urios, V. (2010) From the Mediterranean Sea to Madagsacar: Are there ecological barriers for the long-distance migrant Eleonora's Falcon? Landscape Ecol. 48:485491.DOI 10.1007/s10980-9460-7.

McGrady, M. J., Nicoll, M. A. C. and Thorpe, A. W.M. (2009) Report on fieldwork to study the status and distribution of breeding Sooty Falcons (Falco concolor) on the northern islands of Oman-2009. Reading, UK: Natural Research, Ltd and Centre for Agri-Environmental Research, Reading University. Unpublished Report.

Mellone, U., López-López, P., Limiñana, R. and Urios, V. (2010) Weather conditions promote route flexibility during open ocean crossing in a long-distance migratory raptor. Int. J. Biometeorol. 10: 413-431.

Moreau, R. E. (1969) The Sooty Falcon, Falco concolor, Temminck. Bull. Br. Ornithol. Club 89: 62-67.

Peveling, R., McWilliam, A. N., Nagel, P., Rasolomanana, H., Raholojaona, L., Ravoningatova, A., Dewhurst, C. F., Gibson, G., Rafanomezana, S. and Tingle, C. C. D. (2003) Impact of locust control on harvester termites and endemic vertebrate predators in Madagascar. J. Appl. Ecol. 40: 729-741.

Shah, J. N., Khan, S. B., Ahmed, S., Javed, S. and Hammadi, H, A. (2008) Sooty Falcon in the United Arab Emirates. Falco 32: 16-19.

Strandberg, R., Alerstam, T., Hake, M. and Olofsson, P. (2006) The journey of a female hobby across two continents: from Sweden in Northern Europe to Zambia in South Africa. Microwave Telemetry Inc. Newsletter winter 2006: 2. (Columbia, MD: Microwave Telemetry, Inc).

Strandberg, R., Klaassen, R. H. G, Olofsson, P. and Alerstam, T. (2009a) Daily travel schedules of adult Eurasian Hobbies Falco subbuteo - variability in flight hours and migration speed along the route. Ardea 97: 287-295.

Strandberg, R., Klaassen, R. H. G., Hake, M. and Alerstam, T. (2009b) How hazardous is the Sahara desert crossing for migratory birds? Indication from satellite tracking of raptors. Biol. Lett. 6: 297-300.

Stresemann, E. (1954) Zur Frage der Wanderungen des Eleonorenfalken. Vogelwarte 17: 182-183.

Symes, C. T. and Woodborne, S. (2010) Migratory connectivity and conservation of the Amur Falcon Falco amurensis: a stable isotope perspective. Bird Conserv. Int. 20: $134-148$.

Walter, H., ed. (1979a) Eleonora's Falcon. Adaptations to prey and habitat in a social raptor. Chicago, IL and London, UK: University of Chicago Press.

Walter, H. (1979b) Eleonora's Falcon. Chicago, IL and London, UK: University of Chicago Press.

Walter, H. (1979c) The Sooty Falcon (Falco concolor) in Oman: results of a breeding survey. J. Oman Stud. 5: 9-59.

Wink, M. and Ristow, D. (200o) Biology and molecular genetics of Eleonora's Falcon Falco eleonorae, a colonial raptor of Mediterranean islands (24). Pp. 653-658 in R. D. Chancellor and B-U. Meyburg, eds. Raptors at risk. Surrey, BC., Canada: Hancock House and World Working Group on Birds of Prey.

Zefania, S. (2001) Observation of Sooty and Eleonora's falcons in Madagascar and further research necessary. Pp. 151-159 in Wings over Africa. International Seminar on Bird Migration: Research, Conservation, Education and Flight Safety. AprilMay 2001. Tel Aviv, Israel: Society for Protection of Nature. 
SÁLIM JAVED*, SHAHID KHAN, JUNID NAZEER SHAH, ABDULLAH ALI AL HAMMADI Environment Agency - Abu Dhabi, PO Box 45553, Abu Dhabi, United Arab Emirates.

DAVID C. DOUGLAS

U.S. Geological Survey, Alaska Science Center, 3100 National Park Rd., Juneau, AK 99801, USA.

*Author for correspondence; email: sjaved@ead.ae

Received 4 December 2010; revision accepted 10 April 2011; Published online 26 July 2011 